\title{
Word of Mouth Communication Influence of Online Hotel Room Reservation Confirmation: Case Study of Individual Travelers in Hong Kong
}

\author{
Grace Suk Ha Chan ${ }^{1}$, Anna Chun-Hsuan Hsiao ${ }^{1}$ \& Irini Lai Fun Tang ${ }^{1}$ \\ ${ }^{1}$ Faculty of International Tourism and Management, City University of Macau, Macau, SAR, China \\ Correspondence: Grace Suk Ha Chan, Faculty of International Tourism and Management, City University of \\ Macau, Macau. Tel: 853-8590-2539. E-mail: gracechan@cityu.mo
}

Received: April 27, 2017 Accepted: May 15, $2017 \quad$ Online Published: May 29, 2017

doi:10.5539/ijms.v9n3p76 URL: http://doi.org/10.5539/ijms.v9n3p76

\begin{abstract}
Hong Kong residents tend to spend their holidays by traveling overseas; hence, they reserve hotels online. Moreover, low-cost carriers have become popular and common, thereby resulting in an increase in the number of individual travelers. Accordingly, the online hotel industry can no longer ignore the potential segment of individual travelers. In addition, word of mouth (WOM) is significant in the decision-making process because of the development of Web 2.0. and Travel 3.0. Furthermore, previous studies were analyzed and only a few focus on the individual traveler perspectives on purchasing hotel reservations online. However, individual travelers have different culture and values compared with the public; the former has its own lifestyle, consumer behavior, and ego. Therefore, the investigation of individual travelers when purchasing hotel reservations online is a valuable research topic. Under all situations, WOM has become one of the crucial factors upon which individual travelers base their travel planning and decision. This study used the interpretivist approach to investigate the respondents' experiences and views for exploring and understanding individual traveler's perception. The current study adopted qualitative research toward the effects of WOM communication on purchasing hotel reservations online. To investigate the topic, in-depth interviews were conducted on 15 respondents who are individual travelers and travel alone. The interviews followed a semi-structured format using open-ended questions. Descriptive research was designed to gather the findings. In addition, this study provided the effects of WOM communication on purchasing hotel reservations online from the perspective of an individual traveler. New findings, effects of WOM from an individual traveler's perspective, and recommendations are provided, thereby providing significant guidance to industrial practitioners to improve and formulate marketing strategies.
\end{abstract}

Keywords: word of mouth, online, confirmation, hotel room reservation, Hong Kong

\section{Introduction}

Online purchasing has witnessed a remarkable leap forward (Chiu et al., 2014; Kim et al., 2006; Luo et al., 2012) with confirmation sales increasing by over 19\% annually (Internet Retailer, 2011); the most significant is a distribution channel for the service organization (Chiu et al., 2014). Goldman Sachs (2011) explained that worldwide online retail sales had reached approximately USD1 trillion by the end of 2010. Many economic studies have predicted that online shopping will increase by an average of over $45 \%$ annually (Forrester Research, 2011).

Consumer reviews can be a good indication for word of mouth (WOM) and can influence consumers' purchase decisions (Zhu, 2010). Online review platforms provide guidelines and references for potential consumers before they engage in any consumption (Chevalier \& Mayzlin, 2006; Hu et al., 2009; Liu, 2006). Breaking out of the limited geographic boundaries and time span of conventional WOM, online WOM can measure all consumers' comments and score the tourism product via the e-platform.

Consumers seek information to increase their product awareness and reduce the risk of purchase; however, they may need other intrinsic and extrinsic cues as well. This study will focus on online travel products, particularly hotel product purchases online. We attempted to analyze on effects of online WOM on room price and comment on how they affect the confirmation choice of the consumer. We opted for individual travelers in Hong Kong as a single case study. 
The tourism outbound business in Hong Kong, in which local people tend to travel during their holiday, is steadily increasing. Statistics from the Hong Kong Tourism Board showed that Hong Kong resident departures involved 89 million people in 2015. A 5.4\% increase occurred from 2014 to 2015 from the 84.5 million departures in 2014 (HKTB, 2016). Local consumers spend 70\% (14 days) of their annual leave to travel overseas. Many individual travelers tended to spend their holidays on travel overseas instead of group tours. The number of online travel sales rapidly increased because of the constant emergence of new technologies. The online travel sales of Hong Kong residents were HKD 12.6 billion and HKD 14.8 billion in 2014 and 2015, respectively. Travel sales increased by 25\% from 2014 to 2015 (Euromonitor, 2015). Online hotel booking was convenient for travelers, although risk was still present compared with face-to-face purchasing in travel agencies.

\section{Problem Statement}

Statistics from the Hong Kong Consumer Council (2016) indicated that the overall consumers' complaints decreased by $12 \%$, but a $41 \%$ increase in travel complaints occurred (to 2,642 cases) from 2014 to 2015. The complaints are related to booking hotels (155 cases) and from the online platform about unclear advertising or the equipment of the hotel being different from the online description (i.e., 140 cases) (Hong Kong Consumer Council, 2016). Complaint data are among the crucial elements present that we need to consider; online hotel reservations result in increased complains. If these complains are not considered, then negative WOM will result, thereby hurting the business.

Consumer search for relevant information to their plans to reduce risk; this approach has become an indispensable step in a traveler's decision-making process (Guillet \& Law, 2011). In addition, a Hotel Price Index (HPI) report from hotels.com (2014) indicated that Hong Kong travelers are price sensitive and the lowest spending populations on hotels in the region. WOM communications tended to play a significant role for the Hong Kong travelers' decision-making process. Therefore, many individual travelers intend to view the online comments and room price before they make any confirmation to reduce their risks. Many consumers believe that all the information about hotel products and online comments by fellow customers can provide persuasiveness of online product reviews (Litvin et al., 2008). Many consumers tend to rely on information about the hotel products and services that have been provided by fellow customers (Senecal \& Nantel, 2004), thereby indicating the power and persuasiveness of online product reviews (Litvin et al., 2008). Kardon (2007) explained that customers rely more on peer reviews than on information that is provided by business entities because peer customers are considerably independent and trustworthy (Wilson \& Sherrell, 1993). The most significant elements are reviews by consumers and those by professional editors (Chen \& Xie, 2008). Online information may include hotel information and reluctant their comments from their customers to the public (Lee et al., 2008).

Online reviews have become crucial resources for travelers to evaluate product quality, services, price ranges, and consumption experiences (Dickinger, 2011; Ye et al., 2011). Accordingly, many hospitality firms are maximizing online reviews as a new tool to attract information searchers and, ultimately, brokers (Dickinger, 2011). Additional information in the hotel website had been regarded as a powerful channel to directly market hotels' environmental initiatives to customers (Chan, 2013; Hsieh, 2012).

Previous scholars analyzed the consumers who evaluate online reviews (Ye et al., 2009). Many discussed the factors that influence travelers' adoption of information from online reviews, whereas others analyze the causal relationship between online review and traveler's intentions and behaviors (Filieri \& Mcleay, 2013; Bilgihan \& Bujisic, 2014). Ye et al. (2011) studied the effects of user-generated reviews on online sales. The results show that a $10 \%$ increase in travel reviews ratings would increase online booking by over $5 \%$. These studies mainly focus on online reviews, thereby influencing travelers' attitudes toward tourism products, as well as their traveling intentions or behaviors (Lee et al., 2008; Ye et al., 2009). Additional content has indicated the consumer review and understanding of how individual aspects influence consumers' decision-making. However, only a few studies have discussed how WOM influences the confirmation of their online hotel reservation confirmation.

To fill in the aforementioned research gap, the present study aims to gain a substantially comprehensive understanding of the effects of online review attributes and source features of individual travelers booking confirmations in Hong Kong. Therefore, this research has the following objectives:
1) To analyze the attitude of individual travelers toward online WOM;
2) To evaluate the influences on confirming online hotel reservations for individual travelers,
3) To identify the effects of WOM communications on purchase intention, and
4) To recommend improvements to WOM marketing for hotel marketers. 


\section{Literature Review}

\subsection{Online WOM}

WOM communication has served as a significant source of effects on consumer behavior (Suhubert \& Ginsburg, 2000). Many consumer reviews online are believed to be substantially credible sources (West \& Broniarczyk, 1998). Consumers often refer to reviews prior to making purchases, particularly when the products and services are uncertain (Chen et al., 2004). Many studies have focused on the positive effect of WOM on their product sales experience (Chevalier \& Mayzlin, 2006). Consumers may take other consumers' WOM into their decision-making process when they perceive that the information is true and believable.

WOM in the form of consumer reviews includes two major key metrics, namely, volume of reviewers and valence of reviews (Mahaan et al., 1984; Neelamegham \& Chintagnta, 1999; Liu, 2006). The volume of WOM refers to the extent of communication among consumers. It is regarded as an indicator of the intensity of WOM that plays a dominant role in driving revenues (Duan et al., 2008). Chen (2004) argued that the volume of consumer reviews reflect the momentum of the product. Additional argument may trigger consumer interests and increase awareness. Many consumers believe that numerous reviews may enhance objectivity and be trusted considerably by potential consumers.

The valence of WOM refers to rating the values of the products, thereby reflecting the overall quality of product performance based on a variety of preferences (Duan et al., 2008). Given that consumers take WOM as a relatively credible source of information, the valence of WOM has a strong effect on consumer judgement $(\mathrm{Ba} \&$ Pavlou, 2002). Previous studies (Liu, 2006; Duan et al., 2008) revealed that although WOM information offers significant explanatory power for box office revenue, such power is mainly generated by the volume of WOM rather that the valence, thereby emphasizing the significance of the awareness effect of WOM.

Ye et al. (2008) introduced the number of reviews posted each month as proxy of monthly hotel sales. Accordingly, consumers may search the related product attributes online, and room price will be the main concern before they make any purchase decisions.

\subsection{Outcomes from WOM}

WOM influenced consumer perception of the product and service perception as a result of the effect of consumer comments, judgment, and ratings on the product due to the likelihood of purchase (Peterson, 1989; Martilla, 1971). The positive effect of WOM may reduce the risk during the evaluation of the consumer purchase cycle (Woodside \& Delozier, 1976). Many consumers often believe that WOM can reduce considerable risks (i.e., functional, time, financial, psychological, and social risks) (Roselius, 1971; Settle \& Alreck, 1989). Risk is divided into two major types, namely, financial and psychological risks.

Services are often intangible, and most consumers purchase services online. Thus, a pre-purchase trial is impossible (Berry, 1980; Zeithaml, 1981; Zeithaml et al., 1985). The reason is the nature of the service with special elements, including intangibility, perishability, and inseparability. Accordingly, inseparability leads to high-risk perceptions in the service contexts. Therefore, WOM is likely to be considerably significant in the service industry.

Bickart \& Schindler (2001) suggested that electronic WOM (eWoM), such as online forums, generate more empathy, credibility, and relevance than does information generated by the organization itself (e.g., hotel webpages or travel agency websites). However, previous studies have identified the outcomes of WOM but seldom discussed the WOM related to successful confirmation of the reservation. Therefore, the current study intends to fill in this research gap.

\subsection{Degree on Influence of WOM on Such Outcomes}

Arndt (1967) explained that several factors influence WOM, including the characteristics of the sender and receiver, as well as their interrelationship. These factors represent the context within which interpersonal and non-interpersonal factors, as well as the message characteristics, interact.

The characteristics of the sender and the receiver and their interrelationship: The two major motivations to the acceptance of WOM are perceived interest of the provider in the receiver and expertise of the giver (Dichter, 1996). This issue underlies the significance of the credibility of the messenger. Wangenheim \& Bayon (2004) identified the importance of senders' WOM on a receiver. The aforementioned study investigated WOM receipt when it has been actively sought, rather than in regular conversation, when WOM occurs serendipitously. Hence, this study (Fitzgerald Bone, 1995) supported the effect of source expertise and opinion leadership on the effectiveness of WOM. However, the effect of receiver expertise on the effect of WOM on outcome, which was 
suggested to be negative, had not been supported, thereby suggesting that further investigation is warranted (Fitzgerald Bone, 1995; Gilly et al., 1998; Bansal \& Voyer, 2000).

The ability of WOM to operate within a consumer network appears to be affected by the tie strength or intensity of the social relationship between consumers (Bansal \& Voyer, 2000; Granovetter, 1973). Consumers' backgrounds, opinions, likes, and dislikes indicated that social networks include close primary family and friendship relationships, as well as socially distant and weak secondary associations (i.e., weak ties). "Weak ties" appears to be key in the transmission of information throughout social networks, thereby bridging the gaps between socially cohesive primary groups (Granovetter, 1983). The effect of one customer passing WOM to another is known as the "ripple effect" (Gremler \& Brown, 1999).

The context within which interpersonal and non-internpersonal factors interact: Several situational factors appear to affect WOM acceptance. WOM seems substantially effective when the information was sought by the receiver Although research on this issue had been limited, many studies agree that WOM is most significant in high risk, high involvement contexts, as well as for substantial complex services, such as professional services (Ennew et al., 2000; File et al., 1994; Hogan et al., 2004).

Message characteristics: WOM has been suggested as vivid, which relates to whether information is emotionally interesting, concrete, and imagery-provoking (Nisbett \& Ross, 1980). Anderson (1998) stated that WOM is vivid and novel, and added that although positive WOM refers to pleasant experiences, negative WOM is substantially vivid. In clearly stated WOM, the points raised in the present review need to be addressed. WOM also affects consumer choice and purchase behavior.

\subsection{Online WOM affects Buying Decisions}

WOM has changed significantly with the development of Web 2.0 (Cheung \& Thadani, 2012). Consumer booking intentions and attitudes are affected by WOM (Doh \& Hwang, 2009; Ladhari \& Michaud, 2015). Previous studies (Dellarocas et al., 2007; Cheung et al., 2009) in marketing showed that online comments affect the profit and loss of companies. In a social media survey conducted by Nielsen (2013), 70\% of the interviewees stated that they believe online consumer reviews. However, extreme positive or negative experiences will appear in online reviews (Litvin et al., 2008). In particular, people produced more substantial WOM on negative reviews more than positive review. This partial opinion affects the credibility and effectiveness of WOM. Therefore, a few studies (Banerjee \& Fudenberg, 2004; Hu et al., 2009) discussed that online users of social media will conduct the research and determine multiple sources because they are smart and aware of these biases. Many individual travelers will search online hotel websites prior to making hotel confirmations. Chen (1987) defined independent travel as people being involved in the travel completely, from trip planning to actual travel experience and until the end of the trip. Independent travel is a growing trend worldwide. A survey of previous studies on independent travel showed solicitude for the experience of individual travelers (Hsu \& You, 2005). Therefore, many individual travelers will seek comments online to reduce their risk in choosing hotel accommodation.

\subsection{The Conceptual Model}

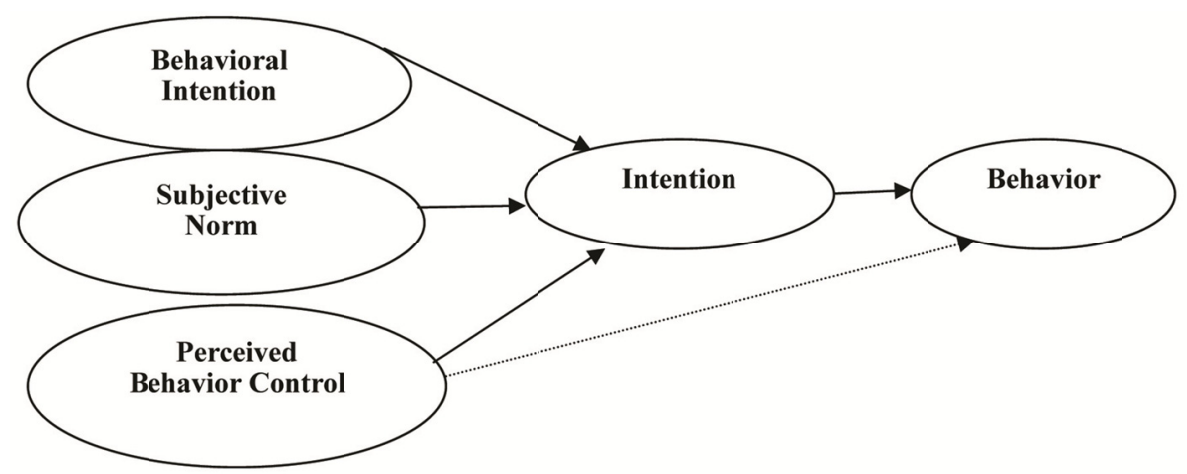

Figure 1. The Planned Behavior (TPB) Model

Sources: Ajzen, 1991. 


\subsubsection{Attitude toward Booking Hotels}

The aim behavior would be to book the hotel via and online platform, and the attitude would be to book using such a platform. Several studies have also rated that WOM is significant in affecting and developing individuals' attitudes and behavioral intentions (Xia, 2008; Sen, 2007; Cantallops, 2014). The positive WOM will provide individual intention. The intentions are assumed to determine the motivational factors that influence behaviors, as well as indicate willingness to attempt and exert effort to realize the behavior and attitude toward making a hotel reservation.( see figure 1)

\subsubsection{Subjective Norms}

Subjective norm is the individual's perception that is influenced by others (Ajzen, 2001). Subjective norms often refer to social pressure whether to perform the behavior. Peer influences often comprise the WOM produced by spouses, family, colleagues, and friends (Teo, 2003). By contrast, external influences are produced by social media, unrelated personal information, and expert information.

\subsubsection{Perceived Behavioral Control}

Ajzen (2001) defined perceived behavioral control as an individual's perception that concerns ease or difficulty is involved when practicing the behavior. People are concerned about their resources and ability. Behavioral control is assumed to reflect past experience and anticipated impediments and obstacles. Given the background of purchasing online hotels, perceived behavioral control relates to the traveler's perception of the satisfactoriness of hotels, the opportunity to travel to that hotel, and to an individual's self-confidence in his/her capability to travel to that hotel. In a study of mobile WOM, Palka et al. (2009) determined that resource-based conditions could affect the recipient's perceived behavioral control.

Perceived behavioral control plays a role in the prediction of intentions and actions. Previous studies (Bandura et al., 1977; Bandura et al., 1980) have shown that people's behavior is strongly influenced by their confidence in their ability to perform it. Beliefs can influence choice of activities, preparation for activities, and emotional reactions (Bandura, 1982). Therefore, WOM may influence consumers' behavioral attitudes, thereby leading to final intention; they confirm their actual behavior by confirming the hotel reservation.

In conclusion, WOM lead to the consumer behavior more favorable the attitudes and subjective norms with respect to certain behavior. (see figure 2) The greater the perceived behavior control, the stronger should be an individual's intention to perform the behavior under consideration. The relative significance of attitude, subject norms, and perceived behavioral control in the prediction of intention is expected to vary across behaviors and situations (Ajzen, 1991).

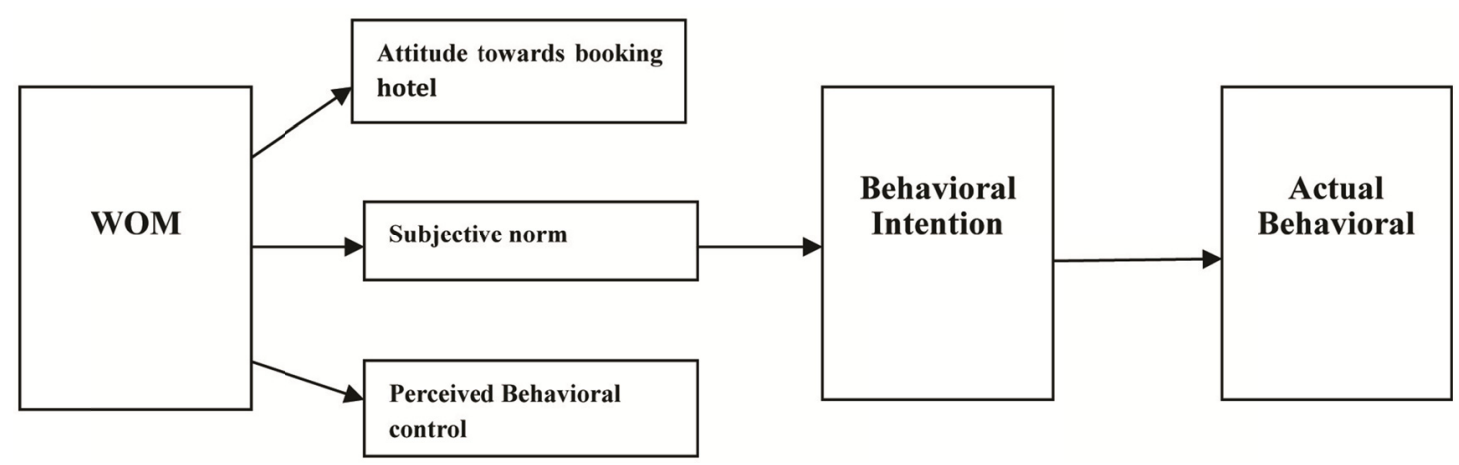

Figure 2. Conceptual framework to show how WOM affects the final decision

Source: Adopted from Ajzen, 1991.

\section{Methodology}

A descriptive qualitative research design was adopted in this study. The data were collected via in-depth interviews with various online users. The interviews began at the end of November 2016 and ended in January 2017. The descriptive research designs collected evidence that enabled the researcher to determine the "who," "what," and "where" of single or multiple cases (Yin, 2003). These designs were often the ideal method to collect information that could demonstrate the relationships and describe the world as it exists. The interviews used open-ended questions, and the data were analyzed using a grounded theory framework. In total, 15 online 
users were selected as purposive sampling. The sample size was considered sufficient to reach information saturation (Webber \& Huxley, 2007). The interviewees had an experience via online reservations in the websites of the hotels or travel agencies. They may have individual travel experiences at least twice in a year and confirm accommodation reservations via websites.

The interviews took 45 mins to 1 hour. The scripts were completely translated from Chinese to English. The interview questions were offered in English and traditional Chinese via a back-translation method. The questions (based on the study objectives) were open-ended. The interview questions are as follows:

1) How do you perceive online WOM in relation to hotel reservation?

2) Do you think that online comments are trustworthy?

3) Do you think that such comments will lead to your purchase intention?

4) What makes you confirm the booking online after you read the comments?

5) Can you recommend to the market how to gain an increase in positive WOM in the online platform, thereby confirming the reservation from individual travelers?

The interviews were conducted in few restaurants.Content analysis was used in the research. The data were summarized and organized following the themes generated by the documentary review. The summaries of the interviews were also prepared to emphasize the main concepts that emerged, as well as to set the context for the quotes to be selected and used as examples in the research report. Data analysis and coding were conducted in several stages. The generated codes were categorized and displayed in themed charts. Domain analysis was used to describe and analyze each theme separately. The coding results at different levels were compared to explore differences in opinions and suggestions. The findings at different levels were synthesized thereafter, and the coding results at different levels were compared to explore differences in opinions and suggestions. The resulting explanations and discussions were compared with the results of previous research. In the present study, in-depth interviews and various secondary data sources (i.e., company websites, journals, and industry reports) were used. The secondary data sources used in this study included articles from universities, government, and nongovernmental organizations; reports obtained from company websites; online information; and promotional materials. The in-depth interviews provided an extensive, first-hand data source; and the secondary materials allowed the researcher to retest the contributions of the respondents. The primary and secondary data and the supporting literature provided a comprehensive, longitudinal, and highly reliable information source that others could easily recheck.

\section{Results}

Table 1 shows the detailed profiles of the respondents. Of the 15 respondents, half were male $(47 \%)$ and half were female (53\%). A total of $60 \%$ of the respondents were aged between 19 and 24 . A total of $53.5 \%$ of the respondents' education levels were certificate, diploma, or higher diploma. Most of the respondents' income was between HKD \$14,001.00 and HKD\$20,000.00 (40\%).

The data collected in this study that comprised primary data (i.e., in-depth interviews), secondary data (i.e., academic journals, Euromonitor's report, and business reports).

Table 1. Interviewees' profiles

\begin{tabular}{llll}
\hline Characteristic & & Frequency & Pecentage \\
\hline Gender & Male & 7 & $47 \%$ \\
& Female & 8 & $53 \%$ \\
\hline Age & $19-24$ & 9 & $60 \%$ \\
& $25-34$ & 5 & $33 \%$ \\
Educational level & $34-45$ & 1 & $7 \%$ \\
& Certificate, Diploma & 8 & $53 \%$ \\
& Higher Diploma & & \\
Income level & Degree & 7 & $47 \%$ \\
& \$8000.00 under & 1 & $7 \%$ \\
& \$8001.00-14000.00 & 4 & $27 \%$ \\
& \$14,001.00-20,000.00 & 6 & $40 \%$ \\
& \$20,001.00-or above & 3 & $20 \%$ \\
& No applicatable & 1 & $6 \%$ \\
\hline
\end{tabular}




\subsection{Attitude of Individual Travelers towards Online Word of Mouth}

\subsubsection{Opinion toward Online WOM in Relation to Hotel Reservations}

The respondents believed that online WOM in relation to hotel reservation is highly convenient. Convenience was a significant point of a hotel reservation's success. Interviewees thought that online WOM was extremely significant and could be a reference in hotel reservation even if the comment may be dubious. The online WOM in relation to hotel reservations showed the complete information more than did the official website. The respondents tended to believe comments that were written by guests. Online WOM was most necessary in their hotel reservation procecss. Most of the respondents thought that online WOM was trustworthy.

\subsubsection{Reasons for Individual Travelers to have Opinions toward Online WOM in Relation to Hotel Reservations}

Overall, positive feelings were more numerous than negative feelings. Accordingly, the respondents claimed that hotel information is extremely significant in long-distance booking. They were concerned about the real environment, guests' satisfaction, and experience. The most frequent reasons were "the comment reflects reality more than the official information." They thought the hotel only provided the best information to the consumer. Therefore, they believed online WOM more than the information provided by hotels or agents. The comment should be impersonal and included negative information.

\subsection{Influence of Online Word of Mouth Communications on Purchase Intention}

A total of 13 respondents felt positive feelings more than negative feelings. Online WOM communication led most of the respondent's purchase intention. Many respondents agreed that online WOM communications affect their purchase intention. Consequently, the respondents created a hotel choice list that is filtered and ranked by the comments.

\subsubsection{Reasons for Online WOM Affect Individual Travelers' Purchase Intentions}

The "positive" respondents were praised for the power of positive WOM. Most respondents believed that online WOM communications and they are affected by positive WOM. Only a segment of the respondents indicated that negative WOM affected their first impression of the hotel, although they will also seek additional information to confirm. If the positive WOM is more than the negative WOM, then they believed that the hotel is good. This result showed that positive WOM is often more powerful than negative WOM. Nearly $80 \%$ of positive travel-related WOM were deemed credible. They sought multiple sources to filter fake comments. The result also showed the celebrity effect on purchase intention. Individual travelers thought that celebrity comments on-line are more credible than those from ordinary people.

\subsection{Influences on Confirming Online Hotel Reservation for Individual Travelers}

\subsubsection{Factors that Influence Confirming Online Hotel Reservations for Individual Travelers}

After reading online comments, the factor influence on confirming online hotel reservations for individual travelers include real environment, convenient location, guest's satisfaction, cost, safety, and privacy. An individual's perception is relevant when making their choice. Individual travelers are concerned about their resources and ability over the best quality.

\subsubsection{Reason for the Factors that Influence Confirming Online Hotel Reservation for Individual Travelers}

The respondents claimed that these factors can influence the confirmation of online hotel reservations. The most frequent reason was "photographs," which is a factor that could reduce the risk and doubt for their travel. They cannot imagine the real situation of the hotel, and the comment could enable them to have a mental image. Ideally, this situation will not have a considerable deviation when they arrive the hotel. The second most frequent reason was "cost effectiveness." They wanted to pay less and get more, thereby facilitating the reduction of the time and monetary costs of their travel. Privacy and safety were the other important factors for individual travelers to confirm the booking

\subsection{Provide Recommendations for Hotel Marketers to Avoid Negative Reviews and Improve WOM Marketing}

\subsubsection{Recommendations}

Most of the respondents provided recommendations about diversification. They required that comments be unbiased, and should include not only the good comments of the hotel. They believed that comments are substantially believable and credible if they contain ideas on shortage. Marketers should analyze and respond to online comments regularly. Determining the problems of the hotel have is significant, as well as developing solutions to address them. Many respondents proposed that comments must include photos taken by guests, thereby reflecting that individual travelers are concerned with the real environment. They believed that the 
official photographs are fake. In addition, certain respondents suggested to invite loyal customers to write the online reviews. Loyal customers should be pleased by the hotel if they return, thereby helping avoid negative reviews.

\section{TPB Model Effect of WOM Impact}

\subsection{Attitude toward Booking Hotel}

The answers to the research questions reflected that many individual travelers indicated their positive attitude toward online WOM in relation to hotel reservations. The attitude comprised making a booking and checking the comment through such a platform.

\subsection{Subjective Norms}

Peer influences produced by spouses, family, colleagues, and friends are difficult to categorize. Online WOM was the external influence that was produced by social media, information from unrelated persons, and expert information. The results of these questions showed that WOM profoundly affected the purchase intention for individual travelers. They were willing to believe WOM, particularly in travel categories.

\subsection{Perceived Behavioral Control}

The answers reflected that perceived behavioral control also affect final decisions. Individual travelers are concerned about their resources and ability. They were willing to choose the cost-effective hotel over the high-quality and enjoyable hotel for their individual trips. Individual travelers cared about a private and safe environment. Under the conditions of their resources and ability, the recipient's perceived behavioral control was affected in that they were also concerned about the cost of travel.

\section{Significant New Findings}

Distinct from previous studies, results in the current study determined additional findings. At present, WOM becoming considerably important affects purchase intention and is significant in the decision-making stage. WOM became an impulse to push them to confirm the booking in many options. By contrast, a few individual travelers become egocentric; they are not affected by other factors or people if they travel alone. In this case, the attitude of the TPB model and perceived behavioral control become considerably important. In addition, they preferred diversification comments that have higher credibility. The comment should include positive and negative perspectives to prove that they are unbiased, under the condition that positive WOM is more prevalent than negative WOM. Although the power of positive WOM is important, a small amount negative WOM that does not affect the purchase intention can help the hotel stand out amongst many competitors.

Table 2. Household income as a factor that affects purchase intention

\begin{tabular}{ll}
\hline Household income as a factor that affects purchase intention \\
\hline High household income & Low household income \\
Accentuated enjoyment & Budget spending \\
Concern hotel facilities & Price sensitive \\
\hline
\end{tabular}

Overall, our findings determined that a significant positive household income effect is significant to purchase intention. The demand for quality hotels may continue to expand as household income increases. The respondents with a substantially high household income were willing to spend. They were concerned about what the hotel can provide more than they were about the price. The influence of hotel facilities was more than that of the price; the former accentuated enjoyment. By contrast, the demand for cost effective hotel products may continue to expand as household income decreases. The respondents with a lower household income were concerned about the price more than with their needs. They were concerned about which hotel can fulfill their basic needs for a cheaper price. They were traveling on a budget. This finding contradicted a conventional belief that every consumer will turn to the cheap price choice when reserving hotels online.

\subsection{Conclusion}

This study focused on analyzing the influence from the WOM effect to confirm online hotel reservations from the perspective of individual travelers. The result of the interviews indicated that Hong Kong individual travelers prefer cost effective hotels. Furthermore, a few of them thought that the positive WOM of hotel is considerably significant. In addition, most of them were concerned with the real situation of the environment and facilities. Furthermore, several individuals preferred that the hotel provide private and safe environments for their travel if 
they travel alone. In addition, individual travelers need visual appeal and positive comments to help them to confirm the online bookings. Their resources and ability affected their choice. Thus, improvement was needed to gain an increase the positive WOM on online platforms as a result can confirm the reservations from individual travelers.

\subsection{Implications for Marketers}

The result of the findings proved that WOM become increasingly important in Web 2.0 for both positive and negative WOM. WOM affects purchase intention and the decision-making stage. Therefore, a few implications are noted for marketers to improve the WOM marketing of their hotel, thereby increasing online purchase. Three implications were suggested for marketers:

This study determined that household income affects the purchase intention. Therefore, marketers should provide additional options on their website. The addition service or facilities should be offered if they pay more or select the deluxe room. It could fulfill their needs and wants for every level of household income.

The results indicated that visuals could be an impulse and stimuli to increase their demand and purchase. Thus, marketers could build up a page on their website that provides visual stimulation such as a virtual tour to their audience. Marketers should consider a virtual reality video, 360, and panorama photo as attractions on their official website. These practices helped to increase demand, as well as allow users to imagine the real situation and confirm the booking.

The current study result also showed the celebrity effect on purchase intention. Individual travelers thought that celebrity comments are more credible than those from ordinary people. Marketers could invite travel bloggers who are well-known to write comments for their hotel.

The findings of this research offered important implications for hotel marketing managers. Online word of mouth played an important role in increasing online purchases, thereby establishing a good image of the hotel. Tourism managers needed to clearly comprehend their target and segmentation. Based on the target consumer needs and want to create a suitable strategy.

\subsection{Implications for Academicians}

Consumers can easily gain information on hotels worldwide. Their experience affected other traveler's intentions and decisions (Ward \& Ostrom, 2003). Researchers who are conscious of this new phenomenon should understand consumer behavior by the new findings and knowledge (Laroche, 2010). In the current study, the influence of online WOM on the decision-making process of a hotel were attempted to be explained. The TPB model provided a basic concept to explain the decision-making process of purchasing hotel reservations online. The current study determined subjectively that the new factor of the TPB model was excluded. In addition, this study was the first that attempted to identify different household income of the different browsers from a different order. The high household income would be based on their need instead of the price. Therefore, future research is needed to compare the different buying behaviors between household incomes.

\subsection{Limitations and Future Study}

This study has three limitations. The main limitation is restrictions because the interview sample size was small. In addition, our study was only limited to the individual travelers in Hong Kong; hence, results may be different in other countries. Any discussion and analysis must be under the frame of these restraints; thus, findings may not be sufficiently representative for all travelers. Future studies can benefit from a cross-sectional analysis of different types of hotel and the purpose of consumer travel. Although this study has limitations, it seems to find interesting results with obvious practical implications.

\section{References}

Ajzen, I. (1991). The theory of planned behavior. Organizational Behavior and Human Decision Processes, 50(2), 179-211. http://doi.org/10.1016/0749-5978(91)90020-T

Ajzen, I. (2001). Nature and operation of attitudes. Annual Review of Psychological Research, 52, 27.

Anderson, E. W. (1998). Customer satisfaction and word of mouth. Journal of Service Research, 1(1), 5-17. http://doi/abs/10.1177/109467059800100102

Arndt, J. (1967). Word of Mouth Advertising: A Review of the Literature. New York, NY: Advertising Research Foundation, Inc.

Aunders, M., Lewis, P., \& Thornhill, A. (2012). Research methods for business students (6th ed.). Bel Air, CA: Financial Times/ Prentice Hall. 
Ba, S., \& Pavlou, P. A. (2002). Evidence of the Effect of Trust Building Technology in Electronic Markets: Price Premiums and Buyer Behavior. MIS Quarterly, 26(3), 243-268. Retrieved from http://www.jstor.org/stable/4132332

Banerjee, A., \& Fudenberg, D. (2004). Word-of-mouth learning. Games and Economic Behavior, 46(1), 1-22. https://doi.org/10.1016/S0899-8256(03)00048-4

Bansal, H. S., \& Voyer, P. A. (2000). Word-of-mouth processes within a service purchase decision context. Journal of Service Research, 3(2), 166-177. https://doi/abs/10.1177/109467050032005

Bickart, B., \& Schindler, R. M. (2001). Internet forums as in uential sources of consumer information. Journal of Interactive Marketing, 15(3), 31-40. https://doi.org/10.1002/dir.1014

Boulding, W., Kalra, A., Staelin, R., \& Zeithaml, V. A. (1993). A dynamic process model of service quality: from expectations to behavioral intention. Journal of Marketing Research, 30, 7-27.

Buttle, F. (1998). Word of mouth: understanding and managing referral marketing. Journal of Strategic Marketing, 6(3), 241-254. http://dx.doi.org/10.1080/096525498346658

Cantallops, A. S., \& Salvi. (2014). New consumer behavior: A review of research on e-WOM and hotel. International of Journal of Hospitality Management, 36, 41-51. https://doi.org/10.1016/j.ijhm.2013.08.007

Chen, Y., \& Xie, J. (2008). Online consumer reviews: word-of-mouth as a new element of the marketing communication mix. Management Science, 23(2), 218-240. http://doi/abs/10.1287/mnsc.1070.0810

Cheung, C. M., \& Thadani, D. R. (2012). The impact of electronic word-of-mouth communication: a literature analysis and integrative model. Decision Support Systems, 54(1), 461-470. https://doi.org/10.1016/j.dss.2012.06.008

Cheung, M. Y., Luo, C., Sia, C. L., \& Chen, H. (2009). Credibility of electronic word-of- mouth: informational and normative determinants of on-line consumer recommendations. International Journal of Electronic Commerce, 13(4), 9. http://doi/abs/10.2753/JEC1086-4415130402

Chevalier, J. A., \& Mayzlin, D. (2006). The Effect of Word of Mouth on Sales: Online Book Reviews. Journal of Marketing Research, 43(3), 345-354. http://dx.doi.org/10.1509/jmkr.43.3.345

Consumer Council. (2016). Overall Consumer Complaints Down 12\% amidst Travel Complaints Rising 41\%. Retrieved from https://www.consumer.org.hk/ws_en/news/press/2015/yearender.html

Dellarocas, C., Zhang, X. M., \& Awad, N. F. (2007). Exploring the value of online product review in forecasting sales: the case of motion pictures. Journal of Interactive Marketing, 21(4), 23-45. https://doi.org/10.1002/dir.20087

Dichter, E. (1966). How word of mouth advertising works. Harvard Business Review, 44(6), 147-160.

Doh, S. J., \& Hwang, J. S. (2009). How consumers evaluate eWOM (electronic word-of-mouth) messages. Cyberpsychology \& Behavior, 12(2), 193-197. https://doi:10.1089/cpb.2008.0109

Duan, W., Guand, B., \& Whinston, A. B. (2008). Do Online Reviews Matter? An Empirical Investigation of Panel Data. Decision Support Systems, 45(4), 1007-1016. https://doi.org/10.1016/j.dss.2008.04.001

Ennew, C. T., Banerjee, A. K., \& Li, D. (2000). Managing word of mouth communication: empirical evidence from India. International Journal of Bank Marketing, 18(2), 75-83.

ESDLife. (2016). The Hong Kong Consumer Travel Spending Pattern 2015. Retrieved from http://www.esdlife.com/home/Default.aspx

Euromonitor. (2016). Travel in Hong Kong China 2015. Retrieved from https://www.portal.euromonitor.com/portal/account/klp

Fitzgerald, B. P. (1995).Word-of-mouth effects on short-term and long-term product judgments. Journal of Business Research, 32, 213-223. https://doi.org/10.1016/0148-2963(94)00047-I

Flick, U. (2011). Introducing research methodology: A beginner's guide to doing a research project. London: Sage.

Giampaolo, V., Roberta, M., \& Dimitrios, B. (2015). The influence of e-word-of-mouth on hotel occupancy rate. International Journal of Contemporary Hospitality Management, 28(9), 2035-2051. http://dx.doi.org/10.1108/IJCHM-05-2015-0238

Gilly, M. C., Graham, J. L., Wolfinbarger, M. F., \& Yale, L. J. (1998). A dyadic study of interpersonal 
information search. Journal of the Academy of Marketing Science, 26(2), 83-10

Granovetter, M. (1973). The strength of weak ties. American Journal of Sociology, 78(6), 1360-1380.

Granovetter, M. (1983). The strength of weak ties: a network theory revisited. Sociological Theory, 1, 203-233. Retrieved from http://www.jstor.org/stable/202051

Granovetter, M. (1985). Economic action and social structure: the problem of embeddedness. American Journal of Sociology, 91(3), 481-510.

Gremler, D. D. (1994). Word-of-mouth about service providers: an illustration of theory development in marketing. In C. W. Park \& D. Smith (Eds.), AMA Winter Educators' Conference: Marketing Theory and Applications (pp. 62-70). American Marketing Association, Chicago, IL.

Gremler, D. D., \& Brown, S. W. (1999). The loyalty ripple effect: appreciating the full value of customers. International Journal of Service Industry Management, 10(3), 271-291. http://dx.doi.org/10.1108/09564239910276872

Guillet, B. D., \& Law, R. (2011). Analyzing hotel star ratings on third-party distribution websites. International Journal of Contemporary Hospitality Management, 22(6), 797-813. http://dx.doi.org/10.1108/09596111011063098

Hong Kong Tourism Board. (2016). A Statistical Review of Hong Kong Tourism 2015. Retrieved from $\mathrm{http} / / / \mathrm{www}$.discoverhongkong.com/tc/index.jsp

hotel.com (2016). Hotel Price Index Report 2014. Retrieved from https://zh.hotels.com/

Hsu, T. C., \& You, S. C. (2005). Discussion of women self-help tourists travel experience. Journal of Recreational Sports, 4, 61-67.

Hu, N., Pavlou, P. A., \& Zhang, J. (2009). Overcoming the J-shaped distribution of product reviews. Communications of the ACM, 52(10), 144-147. https://doi.org/10.1145/1562764.1562800

Kardon, B. (2007). They're saying nasty things. Marketing News, 41(20), 30.

Ladhari, R., \& Michaud, M. (2015). eWOM effects on hotel booking intentions, attitudes, trust, and website perceptions. International Journal of Hospitality Management, 46(1), 6-45. https://doi.org/10.1016/j.ijhm.2015.01.010

Laroche, M. (2010). Advances in internet consumer behavior and marketing strategy. Journal of Business Research, 63, 1015-1017. https://doi.org/10.1016/j.jbusres.2009.06.010

Lee, J., Park, D., \& Han, I. (2008). The effect of negative online consumer reviews on product attitude: an information processing view. Electronic Commerce Research and Applications, 7(3), 341-352. https://doi.org/10.1016/j.elerap.2007.05.004

Litvin, S. W., Goldsmith, R. E., \& Pan, B. (2008). Electronic word-of-mouth in hospitality and tourism management. Tourism Management, 29(3), 458-468. https://doi.org/10.1016/j.tourman.2007.05.011

Mahajan, V., Muller, E., \& Kerin, R. A. (1984). Introduction strategy for new products with positive and $\begin{array}{llll}\text { negative word-of-mouth. } \quad \text { Management } & \text { Science, } & 30(12), & 1389-1404 .\end{array}$ http://dx.doi.org/10.1287/mnsc.30.12.1389

Miles, M. B., \& Huberman, A. M. (1994). Qualitative data analysis: An expanded sourcebook (2nd ed.), Thousand Oaks, CA, US: Sage Publications, Inc

Moran, M., Van Cauwenberg, J., Hercky-Linnewiel, R., Cerin, E., Deforche, B., \& Plaut, P. (2014). Understanding the relationships between the physical environment and physical activity in older adults: A systematic review of qualitative studies. International Journal of Behavioural Nutrition and Physical Activity, 11, 79.

Nielsen, A. C. (2006). Tomorrow is a new consumer! Who is the future Asian consumer? Retrieved from www.my.acnielsen.com/reports/documents/AsianConsumer.pdf

Ogden, M. (2001). Marketing truth: hearing is believing. The Business Journal, 16(52), 17.

Palka, W., Pousttchi, K., \& Wiedemann, D. G. (2009). Mobile word-of-mouth-a grounded theory of mobile viral marketing. Journal of Information Technology, 24(2), 172-185.

Patton, M. Q. (2002). Qualitative research and evaluation methods. Thousand Oaks, CA, London: Sage Publications. 
Peterson, R. A. (1989). Some limits on the potency of word-of-mouth information. Advances in Consumer Research, 16, 23-29.

Pricewaterhouse Coopers Hong Kong. (2015). Global Hotel Report 2015. Retrieved from http://www.ey.com/Publication/vwLUAssets/ey-global-hospitality-insights-2015/\$File/ey-global-hospitality -insights-2015.pdf

Roselius, T. (1971). Consumer rankings of risk reduction methods. Journal of Marketing, 35, 56-61. Retrieved from http://www.jstor.org/stable/1250565

Schubert, P., \& Ginsburg, M. (2000). Virtual Communities of Transaction: The Role of Personalization in Electronic Commerce. Electronic Markets, 10(1), 45-55. https://doi/abs/10.1080/10196780050033971

Sen, S., \& Lerman, D. (2007). Why are you telling me this? An examination into negative consumer reviews on the web. Journal of Interactive Marketing, 21(4), 76-94. https://doi.org/10.1002/dir.20090

Settle, R. B., \& Alreck, P. L. (1989). Reducing buyers' sense of risk. Marketing Communications, 14(1), 34-40.

Sigala, M. (2009). E-service quality and Web 2.0: expanding quality models to include consumer participation and inter-consumer support. The Service Industries Journal, 29(10), 1341-1358. http://dx.doi.org/10.1080/02642060903026239

Teo, T. S. H., \& Pok, S. H. (2003). Adoption of WAP-enabled mobile phones among Internet users. Omega-The International Journal of Management Science, 31(6), 483-498. https://doi.org/10.1016/j.omega.2003.08.005

Ufuk, D., Bekir, B. D., \& Sevgi, B. (2015). The role of servicescape and image perceptions of customers on behavioral intentions in the hotel industry. International Journal of Contemporary Hospitality Management, 27(7), 1728-1748. http://dx.doi.org/10.1108/IJCHM-04-2014-0173

Voyer, P. A., \& Ranaweera, C. (2015). The impact of word of mouth on service purchase decisions: Examining risk and the interaction of tie strength and involvement. Journal of Service Theory and Practice, 25(5), 636-656. http://dx.doi.org/10.1108/JSTP-04-2014-0070

Ward, J. C., \& Ostrom, A. L. (2003). The internet as information minefield: an analysis of the source and content of brand information yielded by net searches. Journal of Business Research, 56(11), 907-914. https://doi.org/10.1016/S0148-2963(01)00277-6

Weber, R. P. (1990). Basic Content Analysis (2nd ed.). Newbury Park, CA: Sage.

Webster, C. (1991). Influences upon consumer expectations of services. The Journal of Services Marketing, 5(1), 5-17. http://dx.doi.org/10.1108/08876049110035440

West, P. M., \& Broniarczyk, S. M. (1998). Integrating Multiple Opinions: The Role of Aspiration Level on Consumer Response to Critic Consensus. Journal of Consumer Research, 25(1), 38-51. https://doi.org/10.1086/209525

Wilson, E. J., \& Sherrell, D. L. (1993). Source effects in communication and persuasion research: a meta-analysis of effect size. Journal of the Academy of Marketing Science, 21(2), 101-112. https://doi:10.1007/BF02894421

World Travel Market. (2015). Global Trends Report 2015. Retrieved from $\mathrm{http}: / /$ news.wtmlondon.com/wp-content/uploads/2015/11/Global-Trends-Report-2015.pdf

Xia, L., \& Bechwati, N. (2008). Word of mouth: the role of cognitive personalization in online consumer reviews. Journal of Interactive Advertising, 9(1), 108-128. http://doi:10.1007/BF02894421

Zeithaml, V., Berry, L. L., \& Parasuraman, A. (1996). The behavioral consequences of service quality. Journal of Marketing, 60(2), 31-46. Retrieved from http://www.jstor.org/stable/1251929

\section{Copyrights}

Copyright for this article is retained by the author, with first publication rights granted to the journal.

This is an open-access article distributed under the terms and conditions of the Creative Commons Attribution license (http://creativecommons.org/licenses/by/4.0/). 